\title{
Corruption and Legislative Functions in Nigeria
}

\author{
Usman D. Umaru, Ph.D \\ Department of Public Administration, University of Maiduguri, Borno State, Nigeria
}

\begin{abstract}
The Legislature is an important institution of government in a democratic system of government as Nigeria, especially the bicameral legislature, made up of the Senate and the House of Representative. It was against this background that this study is on the impact of corruption on the function of the legislature. The study adopted content analysis. Documentary ideas as expressed in text books, journal articles, magazines, Internet and Newspapers was analyzed and utilized. Its objective is to identify how corruption scuttled proper democratic representation in the National Assembly in Nigeria. The study discovered that the members of the National Assembly, i.e. Senate and the House of Representative were only concerned with their personal interest and not the interest of the public that voted them into the various houses to represent them. In conclusion, the study identifies corruption as the reason why the National Assembly was not able to do proper legislation. It was therefore recommended that the legislature should be operated on a part-time basis and the number of sittings and the membership at both the lower and upper chambers should be drastically reduced.
\end{abstract}

Keywords: Representative system of government, Legislature and Corruption.

\section{Introduction}

The Nigerian State is made up of three arms of government. These are the Executive, Legislature and the Judiciary. These arms were also referred to as the organs or branches of the government. Each of these branch of the government has a distinct function its performs in the art of governance in a representative system of government.The Executive arm of the government in a presidential system of government such as in Nigeria is headed by the President, assisted by a Vice-president, Ministers with the various ministries and parastatals. The power of the Executive arm of the government is exercised by the President in the appointment of his Vicepresident and Ministers who will head the various ministries in the day to day running of government. The Legislative organ of the government on the other hand, is made up of the National Assembly, consisting of the Senate and the House of Representative. In Nigeria, there are 109 Senators and 360 members of the House of Representative. The Senate is headed by the President of the Senate while the House of Representative if headed by the Speaker of the House, who were elected by the elected representatives in the two houses. In the case of the Judicial branch of the government, it is headed by the Chief Justice of the Federation and it is consisted of the Supreme Court and the lower federal courts. In terms of functions, the Executive arm is responsible for the day to day operation of the government and the collection of revenue, while the Legislature is responsible for making and passing laws and allocating funds for the running of the government. The Judiciary on the other hand is responsible for interpretation of legislation and to hear cases that challenge legislation. These arms of the government that ought to be the bulwark of our democracy have been weakened by inefficiency, incompetence, lack of commitment and corruption. Of particular interest is the legislative arms of the government that has almost been handcuffed and imprisoned by the demon called corruption and has therefore failed to deliver on their mandates, which means that they have failed to make appropriate contributions which would have ensured the sustenance of democracy and good governance in Nigeria. It is against this background of the functions of the legislature, that this study assesses the impact of corruption on the functions of the legislature in Nigeria from 2000 to 2015. The methodology adopted is the qualitative research method which involved the use of documentary evidences sought from the secondary sources of data.

\section{Conceptual Issues}

Government is that central authority which claims allegiance from all members of the state and which is capable of imposing its will on all members of the state if need be by means of force, and which is ready to protect the lives and properties of all members within its confines (Okoli, 2003). There are various systems of government, and of relevance to this study is the representative system of government; which is the selection of members of government through general election to represent their constituencies in either the House of Representative or the Senate, together known as the National Assembly. Those elected representatives work in a legislature. The legislature is the governing body that operates in a building called the Senate building or the House of Representative building, which makes laws, amend or repeal them, for the progress and development of a country (Okoli, 2003). It should not be corrupt. Corruption is the mis-use of public power by elected politicians or appointed civil servants for private gains. Corruption therefore wastes resources, distorts 
budgetary allocations, breeds inefficiency and unpredictability, slows and erodes development and lowers respect for constituted authority (Ogboru, 2009).

\section{Theoretical Framework}

The Elite theory shall be appropriately used to analyse this study.Mbah (2006), stated that Mosca, a theorist of political elite, said that in all societies, two classes of people existed. That is a class that rules and a class that is ruled. The ruling class is always minority and performed all the political functions, monopolizes power and maximizes its enjoyment of socially available values. In politics, the ruling class is seen in terms of a small group dominating the whole society and taking the important decisions which make the mark and history in politics. As such, in a mass participatory democracy such as Nigeria, consensus is generally brought about by a few or supported by them as representative of the people. Therefore, in Nigeria, the 109 members of the senate and the 360 members of the House of Representative are political elites within the class that rules and representing their various senatorial districts and constituencies on behalf of the people of these areas. These political elites, as members of the National Assembly are discriminatory, pre-emptive, and preventive and savours of a divine rightto say what politics ought to be and tend to disregard and snobs mass opinions and competences. They tend to claim and retain powers by perpetuation until circumstances eject or forced them from power. To them, democracy is an uneasy political nomenclature (Mbah, 2006).

\section{Literature Review}

A Legislature can be bicameral or unicameral. A bicameral legislature consists of two houses (chambers), the upper and the lower house. Countries with bicameral legislatures include United States of America, United Kingdom and Nigeria. In the case of unicameral legislature, it refers to a legislature that is consisted of one house or chamber. Countries with unicameral legislatures are United Arab Emirate, Poland, Denmark, Finland, Israel, Spain, Cote 'd voire, Senegal, New Zealand, Tanzania and Sierra Leon (Okoli, 2003). The legislature in Nigeria is bicameral. That is, it consisted of two houses, made up of the Senate and the House of Representative. The Senate is known as the upper house, while the House of Representative is known as the lower house. Both houses are referred to as the National Assembly. By adopting bicameralism, Nigeria enjoys the following advantages: bicameralism accommodate different groups in either the upper or lower house and ensures the success of federalism; bicameralism also ensures that bills and legislations are properly and exhaustively discussed before they become law, thus preventing the arbitrary and whimsical imposition of laws on the people by a single house (Okoli, 2003).

The functions of the legislature are law making; strict surveillance over the actions of the executive; amending the constitution whenever the need arises; control national finances through regulation of borrowing, taxation and supervision of governmental expenditures; publicizing issues and bring them to public focus; plays active and decisive roles in major appointments to the executive or judicial offices; plays active part in negotiating and ratifying treaties and delegates law-making authority to certain executive ministries and quasilegislative bodies such as boards, agencies, commissions and parastatals (Okoli, 2003). However, the 1999 Constitution of the Federal Republic of Nigeria assigned three roles to the National Assembly. These are legislation, appropriation and oversight functions. Under the legislation, they are empowered to make and unmake law such as the Freedom of Information Law; under appropriation, they approve the executive expenditure such as Budget and in oversight, they are suppose to supervise, regulate and control the Ministries, Departments and Agencies (Agbo, 2012).

\section{Oversight Function of the Legislature}

The Oversight function of the legislature is a very important factor in democracy, because without it, all the other arms of government can do whatever they like without intervention. Oversight is the process of asking questions, which come in the form of investigative probes with the attendant public hearings, with live coverage (Ogene, 2012). It has been observed by Nigerians that both houses of parliament leverage on the oversight functions to enrich individual members instead of monitoring governance. This is because some Ministers, Director-Generals of Departments and Agencies and Chief Executives of Companies whose establishments had come under public scrutiny, had alleged that they had faced intimidation and extortion from law- makers. These law-makers struggle to be in "lucrative" committees with potential for probes, public hearings and oversight visits. From 2008 to 2012, at least 35 major probes had been carried out by the National Assembly in the exercise of their oversight functions. 
Table 1: List of National Assembly Probes from 2008 - 2012

\begin{tabular}{|l|l|l|}
\hline S/No. & Probe & Year \\
\hline 1 & House of Rep. probe of Energy Sector & 2008 \\
\hline 2 & Senate probe of FCT Minister, El-Rufai & 2008 \\
\hline 3 & House of Rep. probe of Railway project & 2008 \\
\hline 4 & Senate probe of Jos crisis & December, 2008 \\
\hline 5 & House of Rep. probe of Finance Ministry over 2007 budget & 2008 \\
\hline 6 & House of Rep. probe of Jos crisis & January, 2009 \\
\hline 7 & House of Rep. probe of Customs scam & January, 2009 \\
\hline 8 & Senate probe of Obasanjo and Yar'Adua on solid minerals special account & February, 2009 \\
\hline 9 & NASS probe of World Bank Aviation loans of 2006 & March, 2009 \\
\hline 10 & Senate probe of Federal Government sales of houses in Lagos and Abuja & 2009 \\
\hline 11 & House of Rep. probe of sale of Nigerian House in New York & February, 2010 \\
\hline 12 & Senate probe of lead poisoning in Zamfara State & 2010 \\
\hline 13 & Senate probe of NIMASA and Shippers' Council & 2008 \\
\hline 14 & Senate probe of Ajaokuta Steel Company concession & March, 2008 \\
\hline 15 & Senate probe of Transport Ministry, 1999-2008 & May, 2008 \\
\hline 16 & House probe of NNPC fund & 2009 \\
\hline 17 & Senate probe of transport sector & September, 2008 \\
\hline 18 & House of Rep. probe of the Salami/Katsina-Alu face-off & 2011 \\
\hline 19 & Senate probe of Establishment and Public Service-Pension & 2012 \\
\hline 20 & Senate probe of the Bureau of Public Enterprise - BPE & 2012 \\
\hline 21 & House of Rep. probe of the Capital Market & 2012 \\
\hline
\end{tabular}

Source: Agbo, 2012.

Table 1 above shows the National Assembly probes for four years, i.e. from 2008 to 2012 .

The Law-makers in the National Assembly have turned probes and public hearings into marketing assets. Every committee struggles to conduct at least one probe. The pattern in the life cycle of a typical committee oversight activity of the National Assembly starts by discovering a target institution, then a motion of "urgent national importance" is raise during the plenary to draw attention to the problem in the sector. The plenary to draw debate is thrown open and later referred to the appropriate committee to investigate. The committee will then order a public hearing. During the hearing, the process goes through the assault stage where the invitees are pummeled to submission, if they are not confident enough or made amenable to settlement, followed by the agreement stage and possible apologies. The report is then released with en ought loop-holes for the accused person to escape with most of his/her loot. For example, the report of an Investigative Committee that probed the management of Pension Fund in Nigeria that was submitted to the Senate, reported widespread looting, with over N58 billion pension funds reported missing and N273.94 billion was the difference between what was received and what was paid out. The Pension Task Force Team headed by Abdulrasheed Maina was asked to refund N15,386, 122.96 being the differentials between the claims of payment of pensions by the task force team and the actual expenditure thereto. The committee also recommended the arrest and prosecution of Maina, John Yusuf, B.G. Kaigama and all members of the pensions Task Team for crimes of fraud, embezzlement, misappropriation, misapplication, illegal virement, contract splitting, and award of contract to non-existing companies and outright stealing of pension funds, which should be recovered from them. But Maina and some members of his team, including a representative of the Independent Corrupt and other related offences Commission (ICPC) on the committee stated that the report is incompetent. In addition, a source in the presidency describe the report as a product of fraud as a result of the poor intellectual ability of most law makers that affect their contribution to debate and investigations (Agbo, 2012).

Also, the House of Representative committee on Capital Market performed poorly when they took on Arumah Otteh, former Director-General, Security and Exchange Commission. The Director-General discovered during the public hearing that some of the committee members have little knowledge of the issue they were probing. This kind of performance gives the impression that law makers undertake oversight function for reasons other than the noble cause. Another case of poor oversight function by the legislature was the Senate Committee on Communication probe of poor GSM services. The legislators were alleged to have received N4.4 million recharge cards from a major service provider in order to overlook complaints of high call rates, thus refusing to ease the plight of consumers (Agbo, 2012). 


\section{Corruption in the National Assembly}

An Elder Stateman in Nigeria, Alhaji Yusuf Maitama Sule (Dan Masanin Kano), stated that what Nigeria has as politicians today were a large chunk of irresponsible people, who were job seekers and businessmen, who came to look for their daily bread; who did not come give b ut to take away; did not come to lead but loot, which they were doing blindly (Nmeribeh, 2010). This statement was as a result of the actions and behaviours of the second republic legislators who came on board in 1999, when Olusegun Obasanjo was elected as the President of Nigeria and his party, the Peoples Democratic Party (P.D.P.) commands the majority in the National Assembly. With this development, the President and the PDP Governors would have no need to lobby so hard and bribe their way to get their bills passed. Right from then, the members of the National Assembly concerned themselves with money spinning projects to grow fat at public expense. Law making became synonymous with money making (Mbah, 2002).

The first thing the Senators did in 1999 when they came to the Senate was to collect N3.5 million each as furniture allowance, despite the cry by Nigerians against it, and which was ignored by the Senators and one of them stated that they were not in Abuja to share poverty. The same Senators collected N1 million each to override the Electoral Act of 2002 and N3 million each as bribe to drop the impeachment bid against the then President Olusegun Obasanjo (Mbah, 2002). In the case of the House of Representative, the members were perpetually at war with one another over money to be shared among them and not about development of Nigeria. Even some members of the House have accumulated hotel bill of N110 million for long period of lodging of their relations and girl friends. Within the same period, the then Speaker of the House of Representative, Ghali Umar Na'Abba, accused the then President Olusegun Obasanjo of bribing Members to impeach him. The bundles of the money meant for the impeachment bribe was displayed on the floor of the House of Representative for Nigerians to see (Mbah, 2002).

The activities and actions of the Members of the House of Representative were so appalling that Nigerians were faced with the ordeal of their representative fighting over looted public funds and sharing it among themselves. It was believed that all the State Assemblies members were simply in the pockets of their respective Governors (their pay-masters), who ensured that there was nothing like dissenting voices. The then Governor of Kaduna State (Ahmed Makarfi) was accused of bribing some members of the Kaduna State House of Assembly with N15 million to impeach the Speaker and his Deputy. The money was displayed on the floor of the house for the citizens of Kaduna State to see. In Benue State House of Assembly, the Speaker, Margaret Icheen, resigned because according to her, the Benue State House of Assembly was stinking of corruption due to the resolve of the members to wine and dine with corruption. In the same vein, the Legislative Houses in Ondo and Kogi States were aware of the allegations that their Governors the, Adebayo Adefarati (Ondo State) and Abubakar Audu (Kogi State) have fraudulently enriched themselves. The then Governor of Kogi State did not deny owing properties worth several millions of dollars abroad which he acquired after becoming Governor. These made Nigerians to believe that the Legislators at both the Federal and State levels only come alive and engage in robust debate only when there is graft money to be shared and cared about nobody but themselves and their martinettes (Mbah, 2002).

\section{Corruption by the Legislative Leadership}

The corruptions taking place in both the National and State Assemblies were as a result of the involvement and collaboration with the leadership of both houses. In the first republic, the then Senate President, Ewerem was removed from office in 1999 and replaced with Senator Chuba Okadigbo, because it was alleged that he collected N25 million for the purchase of furniture and also received a bribed of N6 million from the street light contract. Within the same period, the Senate President, who replaced Evans Ewerem, Chuba Okadigbo and his Deputy, Haruna Abubakar were impeached, because the Senate President allocated to himself the sum of N37.2 million as furniture allowance; bought cars for N30 million; receives N29 million for Christmas; approved N600 million as consultancy fees and N70million for the construction of office complex and the purchase of ram. His Deputy (Haruna Abubakar) received N16.9 million for Christmas and N3.2 million for Sallah. Other allegations include N175 million contract for the street lightning of Eagle Square instead of N57 million estimated by the Federal Capital Territory and N7 million spent on gardening (hip-hip for the green party). These contracts were given to unregistered companies (Ogoh, 2000).

When Chuba Okadigbo was removed as Senate President, he was replaced by Senator Pius Ayim as Senate President. Pius Ayim was also alleged to have involved himself in some shaddy deals such as awarding contract for N15.9 million for the supply of National Flag; N4.8 million for the repair of car attached to his office; N917.82 million for the purchase of Peugeot 406 cars for Senators; collection of N10.29 million as eastacode allowance etc.( Ogoh, 2000). 
Ghali Umar Na'Abba was a former Speaker of the House of Representative. He was alleged to have mismanaged N20 million meant for the construction of a Press Centre and also collected an overdraft of N1.5 billion together with approving for himself the sum of N22.9 million (Okoro, 2002). Another former Speaker, Patricia Olubumi Etteh who was the first female Speaker in Nigeria was impeached because she approved the sum of N238 million renovation contract of her official quarters without going through due process. She also approved the sum of N600 million for the purchase of a Body Massage Machine (Abimboye, 2011). Dimeji Bankole who took over as Speaker from Patricia Etteh, was equally alleged to have misappropriated N9 billion out of N11 billion capital votes of the House of Representative in the 2008/2009 Budget to corrupt practices. He also took a bank loan of N10 billion to finance the activities of the house without the knowledge of the members (Abimboye, 2011).

The $8^{\text {th }}$ Senate which was inaugurate on the $9^{\text {th }}$ of June 2015 , seem not to be at par with the mood of Nigerian public, because in the midst of the economic hardship afflicting Nigerians, the Senate imported 36 sports utility vehicles twice the original price, each at N36.5 million. But in defending the action of the Senate, Senator Ibrahim Gobir, Chairman Senate Committee on Senate Services said:

The Upper house never spend over N4 billion to purchase 108 cars for law-makers as alleged in some quarters. Only 36 SUVs were bought at the cost of N36.5 million each. ....we had a close session and they agreed that we should vie one car per state; we sat down and agreed on who among the three Senators from each state needs the car most and that was what happened (Williams, 2015).

Senator Gobir dismissed the criticism from Nigerians about the Senate's insensitivity in spending such money on cars, given the country economic challenge. He then said: "come to think of it, there is no Minister that has not got about three, four cars - one Land Cruiser, may be a back up and two Hilux cars. There is no Director in the Civil Service that hasn't got a car. There is no Permanent Secretary that hasn't a Land Cruiser. In fact, every House of Assembly member has either a Prado or a Land Cruiser and here is a Senator, you say he cannot have one Land Cruiser." (Williams, 2015).

\section{Ministerial Nominee, Bill passage and Corruption in the Legislature}

It has been alleged that Nigerian Legislators at the Upper chamber (Senate) do demand for bribes from ministerial nominees to facilitate their clearance at the Senate. These allegations came to the view when a Ministerial Nominee during the era of President Obasanjo, Mallam Nasir El-Rufai, alleged that Senator Ibrahim Mantu and Senator Jonathan Zwingina requested him to pay the sum of N54 million bribes to facilitate his clearance at the Senate. Also, another Ministerial Nominee, Miss Funke Adedoyi was told to play N100 million, but an official in the Presidency then, who was very close to her, provide some part of the money. Furthermore, Prof. Babalola Borishade, a former Minister of Education was equally approached by some Senators to pay them N50 million to facilitate his clearance (Akintunde, 2003).

In 2011, the House of Representative was expected to pass the Petroleum Industry Bill (PIB), which was earlier passed by the Senate. But the Multi-national companies were fighting seriously to ensure that the bill if passed at all should be in their favour. Because of this, there was an allegation that the Law-makers were given the sum of $\$ 10$ million dollars to pass the PIB in a form that will favour the Oil companies. Also, the Legislators were alleged to have demanded the sum of N600 million before they would agree to pass the Sovereign Wealth Bill (SWB), which seek to promote fiscal discipline and ensure better utilization of excess crude profit. The Bill was sponsored by the Presidency (Suleiman, 2011).

In the same vein, Representative Farouk Lawan and Mr. Emenalo Boniface collected \$3 million bribe with a view to ensure that Zenon Petroleum and Gas Ltd. Escape prosecution, even though the committee had ab-initio found it culpable in fuel subsidy fraud. An offence which is contrary to Section 17(1) (a); 8(1) (a) (b) (ii), and 23 (i) of the Corrupt Practices and Other Related Offences Act 2000 and punishable under Section 8(1) 17(10 and 23(3) of the same Act. Hon. Farouk Lawan was the Chairman of the House of Representative Ad hoc Committee on Monitoring of Fuel Subsidy. He corruptly obtained for himself $\$ 500,000$ from Mr. Femi Odetola, Chairman of Zenon Petroleum and Gas Ltd. As an inducement to remove the name of Zenon Petroleum and Gas Ltd. From the report of the House of Representatrive. Also, Mr. Emenalo Boniface, a public official and an Assistant Director, who was the Secretary of the Committee received from Mr.Femi Odetola the sum of $\$ 300,000$ for himself (Nnochiri, 2013).

\section{Nigerian Constitution and Membership of the National Assembly}

As a result of the various allegations of corruption that had plagued the National Assembly (Senate and House of Representatives) from 1999 to 2015, it has become germane to take a look at the provisions of the 1999 Constitution of the Federal Republic of Nigeria as it relate to the membership of the National Assembly, in terms of the exclusions of certain categories of Nigerians from being members of the National Assembly and the reasons for that. Section $66(1, \mathrm{a}-\mathrm{i})$ of the 1999 Constitution stipulated that no person shall be qualified for election to Senate or the House of Representatives, as such unworthy of making laws for the country, if he/she 
amongst others, has been indicted for embezzlement or fraud by judicial commission of inquiry or administrative panel of inquiry or a tribunals set up under the Tribunals of Inquiry Act, Tribunal of Inquiry Law or any other law by the Federal or State government which indictment has been accepted by the federal or state governments respectively.In addition, members of secret societies, persons with forged certificates and undischarged bankruptcy were also disqualified. It has therefore been discovered that none of the 469 (109 Senators and 360 members of House of Representatives) members of the $8^{\text {th }}$ National Assembly, with criminal allegations based on the above provisions of the law, were indicted (1999 Constitution).

Table 2: Nigerian Legislators Facing Criminal Allegations

\begin{tabular}{|c|c|c|}
\hline S/No. & Name of Legislators & Criminal Allegations \\
\hline 1 & Senator David Mark & $\begin{array}{l}\text { Court papers in London showed that in the early 2000s, He operated foreign } \\
\text { accounts with six million pounds: three at the Northern Bank, Isle of Man, and } \\
\text { one at the Allied Irish Bank, Jersey. }\end{array}$ \\
\hline 2 & $\begin{array}{l}\text { Hon. Iorwase Hembe and } \\
\text { Hon. Ifeanyi Azubuogu }\end{array}$ & $\begin{array}{l}\text { The duo were accused by the former Director-General of the Security and } \\
\text { Exchange Commission of demanding N } 39 \text { million bribes and an additional N5 } \\
\text { million, during the probe of the near collapse capital market in 2012. }\end{array}$ \\
\hline 3 & Senator Bukola Saraki & $\begin{array}{l}\text { He was alleged to have violated Nigeria's Money Laundering laws as a result of } \\
\text { the consistent stealing of public funds through his personal assistant, Abdul } \\
\text { Adama and other staff who helped him in laundering the monies in bits. They } \\
\text { were recommended for prosecution for offenses relating to Money Laundering } \\
\text { Act and Forex (4Monitoring and Miscellaneous Provisions) Act. The former } \\
\text { Attorney General and Minister of Justice, Mohammed Adoke directed the } \\
\text { Inspector-General of Police to stop further investigation. }\end{array}$ \\
\hline 4 & Senator Theodore Orji & $\begin{array}{l}\text { The Senator was linked to the withdrawal of N5.6 billion in cash from Abia State } \\
\text { accounts in the Guarantee Trust Bank, against the regulation of the Central Bank. } \\
\text { He was the conduit through which Abia state was defrauded during the } 8 \text { year } \\
\text { reign of his godfather, Kalu. He was in the detention of the EFCC when he won } \\
\text { the Governorship election in Abia State, he was released be of the constitutional } \\
\text { immunity. He is yet to be cleared. }\end{array}$ \\
\hline 5 & Senator Danjuma Goje & $\begin{array}{l}\text { A former Governor of Gombe State. He was alleged to have stolen the sum of } \\
\text { N52 billion Gombe State funds. He was charged to court by the EFCC. The case } \\
\text { is ongoing. }\end{array}$ \\
\hline 6 & $\begin{array}{ll}\text { Senator } & \text { Goodhope } \\
\text { Uzodimma } & \end{array}$ & $\begin{array}{l}\text { He allegedly transferred funds from the account of the National Maritime } \\
\text { Authority to the former Head of State, General Abdulsalami Abubakar. He also } \\
\text { collected N } 250 \text { million mobilization fee, which he made a refund. He was } \\
\text { detained by the EFCC when one of his companies - Transurb Technical Consult } \\
\text { Ltd - went bankrupt. He is yet to be cleared of any of these allegations. }\end{array}$ \\
\hline 7 & Senator Adamu Aliero & $\begin{array}{l}\text { He was a former Governor of Kebbi State. He was alleged to have stolen N10.2 } \\
\text { billion funds of the State. He is yet to be cleared of the charges by the EFCC } \\
\text { and ICPC. }\end{array}$ \\
\hline 8 & $\begin{array}{l}\text { Senator AbdulAzeez } \\
\text { Murtala Nyako }\end{array}$ & $\begin{array}{l}\text { He was the son of the former Governor of Adamawa State, Murtala Nyako. He } \\
\text { was accused of stealing, abuse of office and money laundering by the EFCC. He } \\
\text { was being investigated for laundering N15 billion State Government money to } \\
\text { the account of five companies belonging to him: Blue opal Nig. Ltd., Crust } \\
\text { Energy Nig. Ltd., Blue Ribbon Multilinks Ltd., Tower Assets Mgt. Ltd., and } \\
\text { Blue Ribbon Bureau De Change. He was elected to make laws for Nigerians. }\end{array}$ \\
\hline 9 & Senator Ali N dume & $\begin{array}{l}\text { Nigerian government had alleged that he has links with the insurgent group, } \\
\text { Boko Haram, and that he furnished the sect with information that aided their } \\
\text { operations in the country. He was arraigned before an Abuja High court by the } \\
\text { federal government on a four count criminal charge and tendered a proof of } \\
\text { evidence that indicated the lawmaker made contacts with the Boko Haram sect } \\
73 \text { times. He is yet to be cleared of the charges. }\end{array}$ \\
\hline 10 & Senator Stella Odua & $\begin{array}{l}\text { Allegation of certificate forgery i.e. forged MBA and Ph.D certificates and was } \\
\text { also indicted for corruption by the House of Representatives when she approved } \\
\text { the illegal purchase of two armored BMW cars for a whopping sum of N255 } \\
\text { million. She has not been cleared of the allegations. }\end{array}$ \\
\hline 11 & Senator Sam Egwu & $\begin{array}{l}\text { He was accused of stealing billions of funds belonging to Ebonyi State when he } \\
\text { was the Governor.. He gave false declaration of asset. The EFCC arrested and } \\
\text { detained the former Accountant General of the State but the former governor was } \\
\text { not touched. }\end{array}$ \\
\hline 12 & Senator Buruji Kashamu & $\begin{array}{l}\text { He is wanted by the United States government for alleged drug related offences. } \\
\text { Senator Kashamu and } 14 \text { others were charged in } 1998 \text { for their alleged } \\
\text { involvement in an international conspiracy to smuggle heroin into the US. Also } \\
\text { the National Drug Law Enforcement Agency placed him under house arrest in an } \\
\text { attempt to extradite him to the US. The matter is still before a court. }\end{array}$ \\
\hline 13 & Senator Joshua Dariye & $\begin{array}{l}\text { He was arrested by the Metropolitan Police on } 20^{\text {th }} \text { January } 2004 \text { in London with } \\
\text { over } \$ 9 \text { million. While on bail, he escaped to Nigeria and has since not gone back } \\
\text { to clear himself of the money laundering charges the British Government brought } \\
\text { against him. On July } 13,2007 \text {, he was arraigned on a } 23 \text { count charge of money } \\
\text { laundering and theft of billions of naira by the EFCC. His appeal to the Supreme } \\
\text { court was dismissed and ordered to go back to the high court to face his trial. But }\end{array}$ \\
\hline
\end{tabular}




\begin{tabular}{|l|l|l|}
\hline & & he headed to the Senate to make laws for Nigerians. \\
\hline 14 & $\begin{array}{l}\text { Senator Abdullahi } \\
\text { Adamu }\end{array}$ & $\begin{array}{l}\text { He was a former Governor of Nasarawa State. He was arrested by the EFCC in } \\
2010 \text { over allegation of fraudulent award of contracts and stealing ofpublic funds } \\
\text { estimated at N15 billion. He was arraigned by the EFCC on a 149 count charge } \\
\text { of fraud, he made several attempt to the courts to drop the charges against him } \\
\text { but to no avail. He is also in the senate making laws for Nigerians. }\end{array}$ \\
\hline
\end{tabular}

Source: Politico Magazine, $29^{\text {th }}$ June, 2015, page 21-28

Table 2 contained the names of some of the Nigeria's $8^{\text {th }}$ National Assembly members, inaugurated on the $9^{\text {th }}$ of June 2015, whose previous actions fall within the provision of Section $66(1 \mathrm{a}-\mathrm{i})$, i.e. they are facing criminal and sundry charges which cast doubts on their integrity.

\section{Corruption and Budget Padding}

Budget Padding has various meanings attach to it. Padding is defined as using soft materials to give comfort or dishonestly make bills more expensive than they should be (Drenkat, 2016). Padding also means making the budget proposal larger than the actual estimates for the project. This is done either by increasing a project's expenses or decreasing its expected revenue. The goal of project padding is to get approval committee to grant artificially high level of funding to the budget maker'sproposed project. The issue of Budget Padding came to view when the Presidency of the Federal Republic of Nigeria accused the $8^{\text {th }}$ National Assembly of Padding its 2016 Budget with N500 billion, far above the revenue projection and built-in deficit, thus making it impossible for the President to implement the budget, going by the country's economic downturn. Apart from padding the budget, the Law-makers were also alleged to have included projects such as the provisions of boreholes, town halls, foot ball pitches as their constituency project to $\mathrm{b}$ e funded by the Federal Government (Williams, 2016).

The erstwhile Chairman, House Committee on Appropriation, Representative Abdulmunini jibrin, who was sacked by the leadership of the House, blew the whistle on padding the budget and stated that the padding was done after the President signed the bill into law. Abdulmumini alleged that ten (10) House of Representative Committee Chairmen padded their respective committees budget to the collective tune of N280 billion. He further stated that the Speaker of the $8^{\text {th }}$ Assembly, Honourable Yakubu Dogara and three other principal officers unduly pressurized him to appropriate additional N40 billion constituency projects arbitrarily and disproportionately in their favour (Drenkat, 2016). Reacting to the allegation of Honourable Abdulmumini Jibrain,, former President Olusegun Obasanjo stated that Jibrin's allegation of padding has finally vindicated him, when he said that rogues and armed robbers were in the national and state houses of assembly. The former president therefore advised President Muhammadu Buhari to be wary of the law makers and that Nigerians should vote credible people into parliament (Williams, 2016).

While in Riyadh, Saudi Arabia, President Muhammadu Buhari vowed that those involved in the padding of the 2016 budget will be verily punished, because the unauthorized alterations had completely changed the document from the one presented to the Assembly:."

The culprits will not go unpunished. I have been a Military Governor, Petroleum Minister, and Military Head of State and headed the Petroleum Trust Fund. Never had I heard the words "budget pladding." Our Minister of Budget and National Planning did a great job with his team. The Minister became almost half of his size during the time, working night and day to get the budget ready, only for some people to pad it. What he gave us was not what was finally being debated. It is very embarrassing and disappointing. We will not allow those who did it to go unpunished (Williams, 2016).

On his return from Saudi Arabia, President Muhammadu Buhari deployed twenty-two (22) directors from, the various budget units of the concerned ministries, departments and agencies were deployed. The former Budget Officer of the Federation was also removed (Williams, 2016).

\section{Conclusion}

The study has proved that the Senate and House of Representatives chambers were deeply corrupt. This has been attested to by the activities of their various leaderships and committees. While the leaderships were involved in fraud, contract scam, embezzlement and outright stealing, the members of the two houses were mainly involved in bribery and intimidations and also contract scams.

\section{Recommendation}

The number of people representing Nigerians at both the lower and upper chambers of the National Assembly should be greatly trim down by amending Section 48 and 49 of the 1999 Constitution of the Federal Republic of Nigeria, whereby the members of the House of Representative shall be 109, i.e. 3 members per state and one member representing the federal capital, as against 360 . While the Senate membership shall be 72 , i.e. 2 Senators per State and one for the Federal Capital, as against 109 Senators. In addition, the membership of 
both the Senate and House of Representatives shall be on part-time basis, with not more than 336 sittings in four years, i.e. 7 sittings per month and 84 sittings in a year for both members of the Senate and House of Representatives. Members shall be paid a sitting allowance as follows: N40,000.00 per sitting for members of the House of Representative and N50,000.00 per sitting for members of the Senate. These will also require the amendment of Section 63 (1) of the 1999 Constitution of the Federal Republic of Nigeria, which required both the Senate and House of Representative to sit for a period of not less than 181 days in a year and 724 days in four years.

In as much as the appointment of a committee by the Senate or House of Representative will ensure that its opinion would be better regulated and managed by such a committee, it ia hereby recommended that where the report of a committee did not meet public expectations or are found to be faulty and suspicious by either the executive or the general public, such a report should be rejected and another committee constituted. This will reduce the amount of abuses and corruptions associated with the oversight functions of the legislature.Furthermore, the Code of Conduct Bureau should take their responsibilities on accountability very serious. Towards this, the Bureau should ensure that at the end of each legislator's tenure, his/her assets and liabilities declared before taking his/her seat in the National Assembly, as provided for by Section 54(1) of the Constitution of the Federal Republic of Nigeria, are scrutinized and compared with the present worth of the legislator, if found to have illegally enrich himself/herself, he/she should be made to face the wrath of the law.In addition, where it is established that the leadership of either the Senate or the House of Representative is involved in any corrupt activity, he or she should be imprisoned without an option of fine.

\section{References}

[1]. 1999 Constitution of the Federal Republic of Nigeria, pages 27, 31, 32 \& 33

[2]. Abimboye, D. (2010). A House of Fraud. Lagos, Newswatch Magazine, July, page 14

[3]. Agbo, A. (2012). The Oversight Haram. Lagos, Tell Magazine, July, pages 45-51.

[4]. Akintunde, K. (2003). Damaging Allegations. Lagos, The Week Magazine, Oct., page 15-17.

[5]. Drenkat, C. (2016). Budget Padding: Between National Assembly and Law. Abuja, Forefront Magazine, August, pages 16-17.

[6]. Mbah, G. (2002). Valley of Corruption. Lagos, Insider Weekly Magazine, December, page 19.

[7]. Mbah, M.C. (2006). Political Theory and Methodology. Enugu, Rex Charles \& Patrick Ltd.

[8]. Nmeribeh, M. (2010). Nigeria is in a Mess. Lagos, The News Magazine, August, pages 18-23.

[9]. Nnochiri, I. (2013). \$3 million Bribery Scam: Farouk, Emenalo to spend one week in Kuje Prison. Retrieved on $28^{\text {th }}$ August, 2016 from www.vanguardngr.com

[10]. Ogboru, I. (2009). Reflection on External Debt, Corruption and Nigerian Economy. Jos, Jos University Press Ltd.

[11]. Ogene, V. (2012). The Oversight Haram. Lagos, Tell Magazine, July, pages 46.

[12]. Ogoh, A. (2000). Legislootive Duties. Lagos, Newswatch Magazine, Aug., page 6.

[13]. Okoli, E.F. and Okoli, F.C. (2003). Foundation of Government and Politics. Onitsha, Africana-First Publishers Ltd.

[14]. Okoro, M. (2002). Third Republic: A Story of Corruption. Lagos, Insider Weekly Magazine, December, page 25.

[15]. Shehu, M. (2015). Nigerian Legislators Facing Criminal Allegations. Abuja, The Politico Magazine, June, pages 21-28.

[16]. Suleiman, T. (2011). This house has failed. Lagos, Tell Magazine, June, pages 22-23.

[17]. What is Budget Padding? Retrieved on $28^{\text {th }}$ Aug. 2016, from www.ehow.com

[18]. What is Corruption? Retrieved on $26^{\text {th }}$ Auglust, 2016, from www.corruptie.org/en/corruption

[19]. Williams, D. (2016). What Manner of Senate? Abuja, The politico Magazine, May, pages 17-18. 